\title{
Etterforskning av illegal ulvejakt ${ }^{1}$
}

\author{
Paul Larsson, Professor, Politihøgskolen i Oslo
}

\begin{abstract}
This article deals with the investigation of illegal wolf hunting. It analyses methods and procedures of investigation based on a sample of cases and interviews. The police are often criticised when dealing with wolf cases, as this is a field dominated by strong emotions. Police are either denounced for using too many resources or criticised for not treating illegal hunting as seriously as they should. These cases are demanding to investigate. Single pieces of evidence rarely determine the outcome of the investigation. What matters is the totality of the evidence. Investigations vary by type of case. Most cases fall into one of three categories: those in which the police initiate and "build" the case proactively; those in which a hunter is "caught in the act"; and those in which the shooter reports the incident to police him or herself - generally describing it as an act of selfdefence. $^{2}$
\end{abstract}

\section{Keywords}

Wildlife crimes, investigation, policing, rural crimes

Miljøkriminalitet, etterforskning, polisiær virksomhet, landlig kriminalitet

Det er uvanlig at politiet får kjenneskap til illegal jakt på ulv i Skandinavia. I noen tilfeller finner turgåere, jegere eller andre døde ulver, de kan være skutt, forgiftet $^{3}$ eller naturlige årsaker kan ligge bak. Politiet mottar tips om antatt ulovelig

1. Title in English: The investigation of illegal wolf hunting

2. Artikkelen bygger på intervjuer med ansatte innen politiet og SNO over årene 2016 til 2018 som har arbeidet med ulv. Det er 16 intervjuede, 9 fra politiet og 7 fra SNO samt flere samtaler med ansatte i rettsvesenet om tematikken. Geografisk dekker undersøkelsen primært Hedmark og Akershus. Videre bygger det på foreliggende materiale fra dommer, rapporter og annet. En lang rekke samtaler med sentrale aktører i feltet. Prosjektet mottok støtte fra Norges forskningsråd og skjedde i samarbeid med Olve Krange og Ketil Skogen ved NINA som undersøkte holdninger til illegal ulvejakt. Takk til Johanne Ytri Dahl, Annette Vestby, Ketil Skogen og Olve Krange for kommentarer på manus.

3. At en ulv er død av forgiftning betyr ikke at det nødvendigvis er resultat av forsøk på å drepe ulv. 
jakt. Det kan komme fra flere hold, fra rovdyraktivister, lokalbefolkning, skogeiere, jegere eller på annet vis. Solide tips er likevel uvanlig. I noen få tilfeller har politiet selv tatt initiativ til etterforskning og arbeidet proaktivt vanligvis i områder hvor mange dyr forsvinner (hot spots), hvor det finnes solide tips eller hvor det er jaktlag eller jegere som vekker mistanke. Et par av sakene som behandles nedenfor er resultat av politiets aktivitet. Den siste type forhold er de hvor jegere eller bønder selv melder fra om felling, vanligvis hevder de å ha handlet i nødverge.

Ulv kan avlives på mange vis. Det kan skje i nødverge, ved ulike former for lovelig felling, ved at det legges ut giftig åte, i forbindelse med annen jakt, mer eller mindre tilfeldig eller ved systematisk illegal jakt. Det er et bredt spekter, fra ulike former for lovelig felling til den systematiske illegale jakten. Man kan skille mellom noen hovedtyper illegal jakt. På en side er den tilfeldige i forbindelse med annen jakt hvor «muligheten byr seg», noen nødvergesaker er av denne typen hvor dyr skytes uten at de representerer fare. Den systematiske organiserte illegale jakten utgjør det andre ytterpunktet. Den sistnevnte skjer oftest i områder med faste ulverevir og kan pågå over mange år, skadene det kan påføre kan være betydelig.

Ulven i Norge er rødlistet ${ }^{4}$ og Høyesterett har slått fast at det å felle ulv ulovelig er et alvorlig lovbrudd som rammes av straffeloven (HR2016 - 01857A). Bernkonvensjonen ligger i bunnen av lovgivingen. Det er også andre argumenter mot illegal jakt; det påfører dyrene betydelige lidelse, ${ }^{5}$ vansker med å opprettholde en god forvaltning av ulven ${ }^{6}$ og det ødelegger for jegere som ønsker legal jakt. ${ }^{7}$ At et ikke ubetydelig antall ulver har blitt drept ${ }^{8}$ i Norge de siste 40 årene er godt dokumentert (Liberg et.al. 2011, Økokrim 1994). Sannsynligheten for at il-

4. Det vil si den er vurdert å ha en risiko for å dø ut i landet. Ulven globalt sett er ikke truet.

5. Noe som er dokumentert ved svenske obduksjoner av ulv som er døde på «naturlig vis» hvor man i et stort antall individer fant skuddskader ofte av alvorlig art som dyrene har levd med.

6. Et hovedproblem for dagens stamme er genetisk innavl, skyter man ut feil individer vil det forsterkes ved at nytt blod ikke kommer inn - som i sak fra Elverum nevnt nedenfor.

7. Ulven er vanskelig å jakte og står høyt i kurs som jaktbytte for mange jegere.

8. Siden debatten om ulv er så betent så har det blitt reagert på begrepsbruken. Det er store forskjeller mellom å bruke «ta ut», felling, avliving eller drap. Begrepet «ta ut» må betegnes som en ren eufemisme som tildekker de reelle forhold som består i at dyr drepes. Felling brukes oftest når det gis tillatelse til å skyte dyr, felling er også et uttrykk som pynter på, mens avliving gir andre assosiasjoner. I deler av artikkelen benyttes begrepet drap. Det er to grunner til det, den viktigste er at Økokrim benytter det i forbindelse med etterforskning og påtale. Teknisk sett etterforskes sakene som drap og mistenkelige dødsfall (Økokrim 1994). 
legal felling oppdages, at det opprettes sak og dømmes er minimale. I den svenske BRÅ rapporten fra 2007 oppsummeres det slik:

«Med andra ord uppgår antalet fällande domar under 11 år till bara några få procent av det antal brott som beräknas ha begåtts endast under det senaste året. Jämfört med hur många rovdjur som dödas illegalt kan antalet dömda gärningspersoner räknas i promillen. (BRÅ 2007, s. 8)

Få av sakene som etterforskes ender med domfellelse og de straffer som ilegges ligger i nedre ende av straffeskalaen (BRÅ 2007). Det samme er tilfelle i norske saker. Illegal jakt er vanskelig å bevise og behandles stort sett som mindre alvorlige lovbrudd i rettssystemet. ${ }^{9}$

\section{Fra nødverge til organisert kriminalitet}

Etterforskning av ulvedrap krever betydelige ressurser og etterforskes med mange av de metoder som benyttes i ordinære drapssaker med rettsteknikere, avhør, sikring av spor og bevis samt medisinske undersøkelser. Konfliktnivået, særlig innen ulvesonen i Norge, er så tilspisset at det er avgjørende med grundig etterforskning for å avklare de faktiske forhold. Kritikken mot statens naturoppsyn (SNO) og politiet kommer både fra ulveskeptikere som kan hevde at det legges ned for mye ressurser og at det nærmest er galt å etterforske slike saker, ${ }^{10}$ men også fra vernesiden som kan stille spørsmål ved om politiet gjør godt nok arbeid. Politiinspektør Henning Klauseie summerer opp betydningen av omfattende etterforskning i en nødverge sak:

«Det er også derfor (fordi konflikten er betent) vi etterforsker så nøye og har bedt krimteknikere giøre en skikkelig oppmåling for å skaffe et bilde av hva som har skjedd - om ulven var i angrep eller ikke. Vi jobber for å bekrefte eller avkrefte en hypotese og finne ut hva som faktisk skjedde.» (Klauseie til Glåmdalen 2 juli 2019)

9. Det ligger snublende nær å oppfatte dette som et utslag av et antroposentrisk syn hvor naturen og dyr nærmest utelukkende oppfattes som til for mennesket (Krange 2018, Sollund 2017). Kranges artikkel heter: «Hva skal vi med ulv?», et spørsmål som ofte høres rundt om i landet.

10. Stortingsrepresentant Emilie E. Mehl fra Senterpartiet uttalte følgende i lokalavisen Glåmdalen: «Ifølge politiets pressemelding ble ulven «erklært død på stedet», og den er også sendt til obduksjon for å finne ut «hvilken identitet den har». Dette reagerer Sp-politikeren på, og mener at dette «bidrar til å menneskeliggjøre ulven på en måte der den blir framstilt som om det er snakk om et menneske».» (Glåmdalen 3/ 7 - 2019) Kritikken til Mehl retter seg mest mot media sin fremstilling som menneskeliggjør ulven. 
Etterforskningen av denne typen saker dekkes av tre aktører, SNO, lokalt politi og Økokrim. Det er $\mathrm{SNO}^{11}$ som i mange tilfeller kan være først på stedet og som har kompetanse til sikre åsted og bevismateriale, samt å bistå politiets etterforskere. De besitter kompetanse og kunnskap som er viktig for politiet i deres etterforskning. Lokalt politi har ansvar for etterforskningen om ikke sakene oppfattes som for store, prinsipielt viktige eller krevende. I så tilfelle tar Økokrim over etterforskningen. Uansett besitter Økokrim spesialkompetanse på feltet og de bistår ofte lokalt politi i slike saker.

Noen særskilte utfordringer ved etterforskningen av illegal jakt skal nevnes før vi ser på sakene. Disse særtrekkene påvirker metodebruken og måten de etterforskes på.

- Sakene anmeldes ikke av publikum.

- Det mangler vitner som har observert handlingene.

- Bevismateriale mangler eller er i dårlig forfatning.

- Handlingene skjer på steder «langt fra folk».

- Det normative grunnlaget er omstridt.

- Grenene mellom det lovlige og ulovlige kan være utydelige.

Disse forholdene har medført at politiet ofte må spore opp sakene selv, eller «bygge saker» ved å arbeide med proaktive metoder. De sakene man ellers får er enten de hvor det påberopes nødverge og skytter selv sier fra, eller de ytterst få hvor enten forholdet observeres eller spores eksempelvis av SNO.

\section{Proaktiv etterforskning}

Mange former for «moderne kriminalitet» er avhengig av at politiet og andre kontrolletater arbeider målbevisst for å avdekke lovbruddene (Newburn 2011, Bacon 2016). Ulike former for etterretningskunnskap, det kan være tips, overvåkning av «kjenninger» eller spaning, for å nevne noen, benyttes for å styre innsatsen mot personer, grupperinger eller områder hvor man forventer kriminell aktivitet.

Når det gjelder ulv så har man lenge observert at det forsvinner individer fra kjente revirer. Revirene er avmerket på oversikter over rovdyrbestanden lagt ut av Rovdata $^{12}$ og andre. Få dyrearter er så overvåket som den skandinaviske ulven.

11. SNO arbeider med en rekke oppsyn som fjelloppsynet og private oppsyn for skogeiere.

12. https://rovdata.no/Ulv/Kartogfigurer.aspx 
Noen steder har det forsvunnet så mange individer over en rekke år at mye tyder på organisert jaktvirksomhet. Politiet har også mottatt tips, men sjelden så avgjørende at de har medført oppstart av etterforskning. Det hevdes at politiet har forsøkt å komme inn i miljøene lokalt, men dette har vært mislykket.

Det mest kjente eksemplet på proaktiv etterforskning i Norge var i forbindelse med Elverumsaken (Larsson 2018b og Lenth et. al. 2017, Sollund 2017b) hvor politiet ved bruk av telefonovervåkning kom på sporet av et nettverk hvor senere flere ble dømt. Den såkalte Norbottenshärvan fra Sverige (2016-2017) har likhetstrekk med Elverumsaken. Der ble det ikke avdekket jakt på ulv, men derimot på bjørn, jerv og gaupe i et lukket miljø hvor flere var i nær slekt (Bjärvall og Franzén 2017).

Det som utviklet seg til Elverumsaken startet med at Riksadvokaten, etter påtrykk fra Ap og SV, i 2009 ønsket mer aktiv innsats fra rettsvesenet mot illegal jakt på ulv. ${ }^{13}$ Det ble arrangert seminar om temaet hvor viktigheten ble understreket. «Vi ønsker å ta dette problemet virkelig på alvor, sier førstestatsadvokat Roar Østby hos Riksadvokaten til NTB.» Spørsmålet var hva man skulle gjør og hvor.

Økokrim igangsatte sammen med lokalt politi et prosjekt i Hedmark i 2010. Først siktet man inn seg mot et miljø med jegere fra Trysil hvor en var dømt for ulovlig bjørnejakt i 2008. Ulv forsvant i området. Opplegget ble holdt hemmelig, kun fire i politiet i Hedmark kjente til det. Det ble holdt på et «need to know» nivå, politiet fryktet lekkasjer fra egne. Innsatsen mellom 2010 og 2013 ga magert resultat. Få har snakket inngående om metodebruken, men det synes som Økokrim spanet ${ }^{14}$ på miljøet med ulike metoder samt at det ble gjort forsøk på å infiltrere jegermiljøene. Lokalt politi samlet informasjon på ulikt vis, man holdt øyne og ører åpne og fulgte med i åpne kilder som Facebookgrupper. At innsatsen ikke resulterte i noe avgjørende funn er kanskje ikke uventet. Det har vist seg vanskelig å få tips og jegermiljøene er tradisjonelt lukket, særlig mot personer utenfra. ${ }^{15}$ At mange likevel visste hva som foregikk lokalt ble tydelig under tele-

13. https://www.vg.no/nyheter/innenriks/i/6xplr/vil-styrke-innsatsen-mot-ulovlig-ulvejakt Det er å merke seg at Storberget var justisminister på det tidspunktet. Han har senere i en mer lokal rolle kommet med innspill om ulv som uttrykker et noe annet syn.

14. Spaning betyr å planmessig innehente opplysninger på offentlig sted av betydning for en sak. Ellers er begrepet relativt vidt (Dahl 2019, Larsson 2014).

15. Jegergrupper består ofte av personer som har kjent hverandre i svært lang tid, vokst opp sammen, er fra samme miljø og i en del tilfeller også er slektninger. Det er folk en kan stole 
fonavlyttingen hvor et titals personer ringte de involverte med tips om ulv og annet. Man får assosiasjoner til hemmelige selskap og nettverk.

Sommeren 2013 ble definisjonen av organisert kriminalitet utvidet (Larsson 2018a og b). Den ble myket opp for blant annet å kunne fange opp miljøkriminalitet. Økokrim søkte om å få utføre kommunikasjonskontroll sommeren 13, i dette tilfellet telefonavlytting. De koblet seg på «gamle kjenninger», noe som etter en stund førte dem videre til hovedpersonen i nettverket i Elverum. Illegal ulvejakt foregår ofte på sporsnø, og politiet ble klar over jakt på tre ulver den 15nde februar 2014. Det blir skutt etter ulvene, men de slipper fra det med livet i behold. Avlyttingen skjedde «live» av etterforsker hos Økokrim mens jakten pågikk. Den 14nde mars 2014 skyter så hovedmannen en ulv mens han jakter rev på åte. Politiet rykket ut og pågrep ham samme kveld. Den 8nde april ble det igangsatt storaksjon hvor 12 ble pågrepet. Mer enn 60 politipersoner deltok i aksjonen, uten at de på forhånd visste hva de skulle gjøre på Elverum. De fleste antok nok at det var en aksjon mot et narkotikamiljø. Det var fire mann per pågrepet, samt påtalejurister og personell fra Økokrim. Det ble til slutt reist tiltale mot seks.

Dommen i tingretten (14-168573MED-SOST) bygger i avgjørende grad på tekniske bevis. De tiltalte vedgikk seg ikke forholdene. Informasjon fra avhørene ble del av et større puslespill. Tiltales Smarttelefoner ble tømt noe som ga rikelig med data. I forbindelse med kartleggingen av jakten den 15 nde februar ble GPS posisjonering koblet sammen med telefonbruk. Det hele ble visualisert med lyd og bevegelige posisjoner på elektroniske kart som ble vist i retten. Det ble mulig å følge jakten fra minutt til minutt. Tiltalte hevdet det var revejakt, men jaktkyndige opplyste at jaktformen ikke passet for rev, men ulv.

I det andre punktet som omhandlet ulven skutt på åte så fant politiet ulven ${ }^{16}$ og de hadde bilder og lydfiler som dokumenterte det hele. At ulven ble skutt om natta, slik at skytteren ikke kunne være helt sikker på hva det var han skjøt tok retten hensyn til. De faktiske forhold var det lite tvil om, spørsmålet var mer den rettslige fortolkningen av dem. Ankesakene gjaldt derfor lovanvendelsen, særlig om de skulle dømmes etter straffelovens $§ 152 \mathrm{~b}$ (generalklausulen) eller naturmangfoldloven $§ 75$, samt spørsmålet om dette kunne betegnes som organisert kriminalitet (strfl § 60a). Lagmannsretten kom i sin slutning våren 2016 til at de ikke anså handlingene som et brudd på straffeloven, men på naturmangfoldloven.

på. Det kan nok variere noe etter type jakt, men de som driver med illegal jakt kan man anta er mer lukket (Krange, Skogen og Figari 2013).

16. I denne forbindelse ble en pensjonert politimann dømt for medvirkning til å skjule dyret. 
Under dissens ble resultatet at man heller ikke oppfattet handlingene som organisert kriminalitet, noe tingretten hadde. Straffen ble derfor kortere enn i tingretten. Det ble anket på lovanvendelsen. Høyseterett avsa sin dom 1 september 2016 (HR2016 - 01857A) hvor straffene atter ble skjerpet og det ble fastslått at handlingene var brudd på straffeloven. Å få avklart dette spørsmålet var det viktigste for Økokrim og ble betegnet som avgjørende for mulighetene å kunne arbeide med slike saker fremover (Høviskeland 2016). Spørsmålet om organisert kriminalitet ble ikke anket. Hovedmannen ble idømt ett års fengsel, mens tre andre tiltalte fikk straffer på seks måneder, fem måneder og 120 dager. Alle mistet retten til jakt i tre år. For mange, som lever for jakt, oppfattes dette som den strengeste straffen. For en av de tiltalte ble lagmannsrettens dom opphevet, som var frifinnelse, men han ble ikke ilagt dom av HR.

Den illegale jakten ville med all sannsynlighet aldri ha blitt oppdaget om ikke en proaktiv etterforskning med overvåkning hadde avdekket forholdet. Mye tyder på at laget hadde jaktet ulv tidligere og at de ville fortsette med det. Hovedtiltalte skrøt på seg flere skutte ulv over telefon. ${ }^{17}$ Saken hviler primært på teknisk etterforskning, data fra avhør er brukt bant annet for å vise at de jaktet i lag, hvem som var med på jakten. Politiet knytter de siktede personene til tid og sted via GPS og telefoni, de viser at det de holdt på med ulvejakt, at deres intensjoner var å skyte ulvene og samt hvilke våpen som ble brukt. Man kan undres over at de tiltalte ikke benyttet domstolen til å fremstå som «folkehelter» ved å åpent vedgå seg forholdene og underbygge det med de vanlige argumentene om en form for nødrett og motstand mot storsamfunnets «overgrep mot» bygdene. I stedet hevdet de å ha jaktet rev, at de ikke visste hva de andre drev med og så videre (Lenth, Bøckmann og Tønnessen 2017). Illegal rovdyrjakt fremstilles ofte som en form for folkelig motstand mot sentrale myndigheter (Essen 2016). Det er grunn til å spørre hvor reelt dette argumentet er.

Den såkalte Norrbottenshärvan har likhetstrekk med Elverumsaken etterforskningsmessig sett. Politiet startet etterforskning sommeren 2016 opp mot en gruppe jegere, som var i familie, etter at å ha mottatt troverdige tips. De hadde lagt ut åte, med snarer og feller som ble fulgt via jaktkamera (Bjärvall og Franzén 2017). Disse var koblet slik at jegerne kunne følge åtestedet «live». Bruken av kamera gjør at man kan jakte på dyrene når det ikke er sporsnø. Det ble avdekket illegal

17. Over telefon nevner han for flere at dette er ulv nummer elleve han har vært med å felle (dom Tingretten s. 103). 
jakt på jerv, gaupe og bjørn. ${ }^{18}$ Omfanget av aktiviteten var betydelig og foregikk over lang tid. Våpen, ammunisjon, Smarttelefoner, datamaskiner, en bjørneskalle, bjørnefeller og ulike andre feller samt GPS utrustning ble beslaglagt og solid dokumentert.

I følge påtalemyndigheten er undersøkelsen «et skoleeksempel» på hvordan slik saker skal etterforskes. I 2017 ble de fem stilt for retten og hovedmannen dømt for medvirkning til grovt jaktlovbrudd, ikke hva han og de andre var siktet for, grovt jaktlovbrudd. Han dømmes til ett år og fire måneder, saken ankes. ${ }^{19}$

\section{«Nødverge»?}

Hovedspørsmålet for etterforskningen av disse forholdene er «hva har skjedd?» Man starter med et dødt dyr, åsted og en identifisert gjerningsperson. Vanligvis melder skytteren selv fra til politiet. I noen tilfeller finnes det vitner. Sakene kan ligne på ordinær drapsetterforskning. Rettstekniske undersøkelser er av stor betydning. Rettsreglene stiller klare krav til hva som kvalifiserer som nødverge. Det avgjørende er å fastslå om ulven var i ferd med å angripe, det holder ikke at skytteren følte ulven truet sauene eller hunden ved sin tilstedeværelse. ${ }^{20}$ Skytterens handlemåte vektlegges, prøvde han å skremme vekk rovdyret? Ble det skutt varselskudd, var dyrene forsvarlig sikret? Det finnes etter hvert en del nødvergesaker, noen henlegges av ulike årsaker, mens andre dømmes for illegal jakt. ${ }^{21}$

18. https://www.kuriren.nu/nyheter/nya-uppgifterfem-man-gripna-vid-stor-polisinsats8966944.aspx

19. Informasjonen om arbeidsmetodikk stammer blant annet fra materiale og informasjon mottatt fra den svenske påtalemyndigheten.

20. Reglene for nødverge er nedfelt i naturmangfoldlovens §17. «Vilt kan avlives når det må anses påkrevd for å fjerne en aktuell og betydelig fare for skade på person. Eieren, eller en som opptrer på vegne av eieren, kan avlive vilt under direkte angrep på bufe, tamrein, gris, hund og fjørfe.» Ulv er rødlistet og betegnes som kritisk truet, det betyr at det ses strengere på avliving av ulv enn eksempelvis gaupe. Dyrene skal være direkte angrepet, den som har dyr plikter å følge regler om inngjerding og andre forhold som verner dem mot rovdyr.

21. https://www.nrk.no/ostlandssendingen/ulv-skutt-i-nes-1.7753865

https:/www.nrk.no/trondelag/hevder-ulven-ble-skutt-i-nodverge-1.13197901 Saken fra Lierne er interessant mest fordi etterforskeren i saken tipset skytteren om hva han skulle si i avhør via SMS. https://www.dagbladet.no/nyheter/politimann-skulle-laere-ulvejeger-aslippe-straff-i-nattlige-sms-er/68964850 Skytteren døde i en ulykke før saken kom opp, mens politimannen ble dømt i Høyesterett i 2018 for grov tjenestefeil. https://www.dagbladet.no/nyheter/politimann-domt-etter-sms-til-ulvejeger/70246500 Inte- 
17 august 2011 melder NRK Østlandssendingen at en mann i Nes i Akershus har skutt ulv og rapportert det til politiet. ${ }^{22}$ Den ble skutt utenfor huset til skytteren på morgenen. Denne hevder det er nødverge, at ulven var på vei til å angripe de fire sauene han hadde bak et strømgjerde. Ulven skytes på 84 meters hold.

Etter rekonstruksjon av hendelsen og tekniske undersøkelser finner politiet at skytterens forklaring ikke stemmer. ${ }^{23}$ Det sentrale spørsmålet blir: «hvilken fart og retning ulven hadde da den ble felt, og ut i fra det spørsmålet om hvorvidt det forelå en nødvergesituasjon eller ikke da mannen felte ulven.» (Slettemoen 2013) Mannen hevdet $\mathrm{i}$ avhør at ulven hadde gått til direkte angrep på sauene. Obduksjon av ulven viste at det ikke var tilfelle. Den var påskutt nesten rett forfra. I så fall gikk den ikke i retning av dyrene. En taktisk rekonstruksjon av hendelsesforløpet på stedet ble utført og det ble innkalt ekspertvitner som uttalte seg om ulvers atferd i slike situasjoner. Man fant at ulven hadde hatt en fart på rundt $10 \mathrm{~km}$ i timen mot skytteren, at det var en streifende ett år gammel hann som kom fra et område mellom Dalarna og Värmland (DNA bevis). Skytteren hadde ikke avfyrt skremmeskudd eller på andre vis forsøkt å jage vekk dyret. Retten fant ikke at ulven var under direkte angrep og han ble dømt til 120 dagers fengsel, inndragning av våpen og tap av rett til jakt og fangst $i$ to år.

\section{«Tatt på fersken»}

Det er veldig få saker av denne typen. Verken statens naturoppsyn (SNO) eller politiet har ressurser eller muligheter til å være ute i feltet i et omfang som gjør at man kan ta noen for ulovelig jakt mens det skjer. Selv med spissede ressurser hvor SNO holder seg ved kjente jaktområder (revir) til rett tid (sporsnø) vil sannsynligheten for tilfeldig å komme over ulovelig jakt være begrenset. Der det har skjedd så er forklaringen at enkelte ulver har blitt tett overvåket, som i Trysil i desember 2015. Det er ikke uvanlig at man finner giftig åte, men det er ofte vanskelig å finne hvem som har lagt det ut. ${ }^{24}$ Det er et tilfelle fra 2002 hvor det ble lagt ut giftig åte og gjerningsmennene ble «tatt på fersken». ${ }^{25}$ Dette er områder hvor man finner en konsentrasjon av jakt, det er i nærheten av de kjente ulverevi-

ressant sak, hvor jeger selv meldte fra - https://www.msn.com/nb-no/nyheter/norge/elgjegerdømt-til-fengsel-for-å-ha-skutt-ulv/ar-AAHnDpm?ocid=spartanntp

22. https://www.nrk.no/ostlandssendingen/ulv-skutt-i-nes-1.7753865

23. https://www.okokrim.no/fengselsstraff-for-ulvedrap.5991323-416298.html

24. https://www.dagsavisen.no/nyheter/innenriks/giftblandere-i-skuddlinja-1.1450070

https://www.nrk.no/norge/fengsel-for-ulveforgifter-1.504679

25. https://www.nrk.no/norge/domt-for-a-lagt-ut-giftate-1.505846 
rene i Hedemark, Østfold og Akershus. Det som blir tatt utenfor disse områdene er hovedsakelig streifdyr. Det er også disse som er mest problematisk i forhold til sau og annet bufe.

Senhøsten 2015 ble svenske myndigheter klar over at en genetisk viktig ulv var på vei sørover i Sverige. Ulven ble fulgt fra Finland og gjennom Sverige. Den var DNA testet, ble fulgt tett og ble ansett som av stor betydning fordi den kunne bringe inn nye gener i stammen i Skandinavia. Det var en hann på 43 kilo. Svenske Riksvårdsverket fulgte den inn i Norge hvor SNO tok over helt til den forsvant. Det var åpent for ulvejakt i Engerdalen nord for Trysil, dette ble opphevet den 18nde desember fordi man ønsket å verne denne ulven.

Den 17nde desember forsvinner ulven. SNO finner blodpøl på et jorde i Trysil den 19nde og politiet konstaterer at dette stammer fra ulven. Grunneier på stedet hvor ulven ble skutt fikk man ikke kontakt med. Saken tar en ny vending den 21 når grunneier via advokat innrømmer å ha skutt ulven og opplyser at kroppen ligger i ei brakke noen kilometer unna.

I retten fremhevet mannen at det var en impulshandling og at han følte at ulven truet hunden hans. Dette hevdet han ikke under de første frie avhørene og retten festet ikke lit til hans senere forklaring. Ulven var observert av flere i området og tiltalte ble varslet via telefon om at den var i nærheten. Det lå åte på eiendommen ikke langt unna, tre elghoder som var lagt ut for å skye rev. Mye tyder på at ulven nok var interessert $i$ åtet. ${ }^{26}$

Dommen faller nærmere ett år etter, den 15nde desember 2016. Den ble 7 måneders fengsel. Man kan spørre om hva som hadde skjedd om ikke ulven var DNA testet og fulgt tett, slik at politiet fant blod på den dømtes eiendom. Høyst sannsynlig ville aldri forholdet blitt oppdaget og ulven ville kun vært en i rekken som forsvinner sporløst. Flere har spurt hvorfor skytteren innrømmet forholdet, lite tyder på en angrende synder. Når han senere forklarte handlingen med at han var redd for at hunden skulle angripes, så falt dette på tidligere forklaring hvor han nektet at så var tilfellet. Fordi det var en tilståelse ble etterforskningen mindre omfattende enn i andre saker, derved ble flere forhold knapt undersøkt, som andres delaktighet, noe den dømte benekter.

Et annet eksempel, som i enda større grad kan betegnes som «tatt på fersken», er et dansk ulvedrap fra 2018. Siden 2012 har det blitt observert ulv på Jylland. Den 16nde april 2018 ble det oppdaget en ulv på et jorde i Ulfborg på vestjylland.

26. https://www.nrk.no/ho/ulveskytter_-_-opplevde-situasjonen-som-truende-og-skremmende1.13261543 
En mann på 66 ble siktet for å ha skutt ulven med tre skudd fra sin bil. ${ }^{27}$ Etterforskningsmessig var det enkelt fordi det fantes filmbevis. Det var dessuten vitner. Tiltalte vedgikk seg handlingen, men påberopte nødverge, at ulven var en «problemulv» og at den muligens var en hybrid. Analyser fastslo at ulven ikke var en hybrid. Retten fant heller ingen forhold som pekte mot nødverge. I september 2019 falt endelig dom som ble 40 dagers betinget fengsel samt at tiltalte mistet jaktretten i to år. ${ }^{28}$

\section{Nåla i høystakken}

Etterforskning av jakt på ulv kan lett fremstå som «career killers» (Benson og Cullen 1998). Betegnelsen ble myntet på etterforskning av former for økonomisk kriminalitet hvor det ble lagt ned mye arbeid og ressurser, hvor lovbryterne kunne få en viss folkelig støtte og utfallet av det hele var høyst usikkert. For etterforskeren kan det status og karrieremessige fallet etter arbeidet med en sak som går galt bli tøft. Kritikken kan komme fra alle hold, også innad fra egne rekker. Som en i SNO uttrykte det: «En må være glad i å være ute og vant med å få en del kjeft.» De færreste søker seg til politiet for å arbeide med slike saker, det er ikke hva Holmberg (1999) betegner som ordentlig politiarbeid. Ordentlig politiarbeid er preget av at sakene lett lar seg løse, gir uttelling i politiets måleparameter, at de normativt er enkle å forholde seg til i svart/hvitt og har støtte i befolkningen. I stedet fremstår ulvesakene som arbeidskrevende, normativt ambivalente både $\mathrm{i}$ egen organisasjon og lokalsamfunnet, usikre, som gir lite uttelling i pålagte sanksjoner, men også i sentrale styringsmål for politiet. I motsetning til hva som ofte hevdes, settes det av små ressurser i politiet til miljøkriminalitet lokalt. Det er ikke prioritert, selv i ulvesonen. Det er derfor ikke forunderlig at kompetansen til å håndtere denne type saker lokalt kan være liten.

Hovedskillet etterforskningsmessig går på mange vis mellom proaktive og reaktiv saker. De reaktive kan grovt sett deles i to, de med identifiserte personer som knyttes opp mot forholdene og de uten. Bevismateriell av en viss kvalitet er også avgjørende. Det tipses om konkrete personer, om åte og illegal jakt, men finner man sjelden åte eller døde dyr som kan knyttes opp mot mistenkte. Derved har man liten mulighet til å knytte personer opp mot forhold. Hovedproblemet er

27. https://www.dr.dk/nyheder/indland/ulvedrab-ved-ulfborg-blev-fanget-paa-kamera-her-ervideoen

28. https://www.dr.dk/nyheder/regionale/midtvest/ulvedom-67-aarig-faar-40-dages-betingetfaengsel-og-mister-jagttegn 
ikke informasjon, men kvaliteten på den. En etterforsker sier det slik: «Det er så mye rykter, så mye folkeprat. Mye av dette er store mediasaker og da har folk meninger, uansett om de virkelig vet noe eller ei.» Det betyr nødvendigvis ikke at slike tips eller etterforskning av sporene er verdiløst. «Den store utfordringen, etterforskningsmessig, er at det vi har å forholde oss til er ting som er fortalt, men som oftest ikke kan etterprøves.» Tips og data fra etterforskningen kan benyttes som etterretningsinformasjon. Informasjonen kan få verdi i andre sammenhenger. Eksempelvis betegnes etterforskningen av et forhold i Sør-Hedmark som ble henlagt, som avgjørende for hva politiet senere gjorde i Elverumsaken.

\section{Polisiær virksomhet mot illegal jakt}

Forholdet mellom de sentrale myndighetene med Økokrims etterforskningskompetanse på feltet og de lokale etterforskerne er preget av klar rollefordeling og gjensidighet. Økokrim har spesialistene og ekspertisen på feltet og etterforsker de større sakene, men det skjer sammen med lokalt politi med bistand fra SNO. I politidistriktene er det miljøkoordinator hvis ansvar er å være ressursperson innen det svært brede feltet miljøkriminalitet som dekker alt fra arbeidsmiljøkriminalitet, snøscooterkjøring i utmark til faunakriminalitet. Tidligere fantes det et fungerende nettverk med miljøkontakter på lensmannskontorene i flere distrikter, men dette har alltid variert en del og vært styrt av ressurspersoner og idealister.

Lokale og sentrale etterforskerne har til dels ganske ulike tilnærminger til arbeidet. Følgende er representativt for de lokale: «Man er helt avhengig av lokalbefolkningen. Uten dem kommer det ikke mye inn.» Og «Har du ikke lokalkunnskap så er du helt blank. Alle i politiet burde ha jobba ved små lensmannskontor. Her møter man folk i motgang og medgang. Er du der og lever med dem så kan du opparbeide tillit og respekt.»

Samtidig sier en annen: «Ingenting ble etterforsket, det kom jo ingenting inn. Lite ble oppdaget.» Som er en gjennomgangstone. Nærhet betyr ikke nødvendigvis at politiet mottar opplysninger i denne type saker, gruppepresset fungerer slik at det blir tyst. En lensmann uttrykker det slik: «For å si det slik, Ole B (lensmann) ville nok være den siste som fikk vite om det (illegal jakt). Skal en få dette til livs så må en jobbe litt utradisjonelt.» Gruppepresset medfører betydelige problemer med å etterforske lokale, som en politietterforsker påpekte: «Det er uaktuelt med åpne vitenavhør - uansett om de er for eller imot. Begynner du med det så vil de lukke seg. Holde kjeft. Gruppepresset fungerer.»

Det kan fremstå som motstridende oppfatninger av verdien av lokalt politiets virksomhet, men det er nok en forenkling. Det er heller slik at lokalt og sentralt politi har ulike roller. Lokalt politi har større muligheter å følge med på «tempe- 
raturen» der de er, de kjenner folk, oppfatninger, skikker og terreng på en helt annen måte enn sentrale etterforskere. Dette gjør at de kan arbeide forebyggende på en mer smidig måte, de besitter en kunnskap som er avgjørende i etterforskningen. Nærhet gjør dem sårbare for lojalitetskonflikter og påvirkning, en klassisk problemstilling innen politiforskningen (Johansen 1977, Mawby and Yarwood 2011). Noe av den samme påpekes av enkelte fra SNO. Folk blir tause i lokalbutikken når de kommer i sine lett gjenkjennelige biler og antrekk. SNO er likevel ikke politi, de har mye å gi, goder som kan være ettertraktet som skaderegistrering og både jegere og befolkning oppfatter dem i et annet lys enn politiet. De høster respekt som eksperter på fjell, skog, jakt og vilt. Dette betyr at de må ha god kontakt med politiet. «SNO vil kunne gjøre en del lokalt, men vi er ikke politi. Hvis vi avdekker noe så må vi ha politi som kommer med en gang. Dette blir vanskelig når man ikke har lokalt politi som kan trå til» sier en oppsynsmann. SNO kan ordne opp i enklere jakt- og regelbrudd som kan ilegges forelegg, men ved eksempelvis illegal felling av ulv eller bjørn så kan fraværende politi bli kritisk.

Lojalitetskonflikter gjør at det mistenkes utro tjenere i egne rekker. «Det er kollegaer som er på den andre sida» sier en tidligere miljøkoordinator. Han mistenkte tilfeller av ren sabotasje. I verste fall har tjenestemenn aktivt eller passivt motarbeidet etterforskningen. ${ }^{29}$ Mer vanlig er det nok at mange er lite motiverte til å arbeide med rovdyrsaker fordi de føler at de havner i en vanskelig situasjon. «Den bristande folkliga förankringen för rovdjurspolitiken skymtar också fram inom polisen, där det förekommer lojalitetskonflikter.» (BRÅ 2007, s. 11) Det kan medføre trenering av saker, dårlig arbeid og nedprioritering. Både ansatte innen SNO og Økokrim uttrykker at de tidvis har hatt en følelse av å bli motarbeidet av lokalt politi (Økokrim 1994).

\section{Ressurser, kompetanse og vilje}

Miljøkriminalitet har aldri vært noen budsjettvinner i politiet, situasjonen de senere årene har vært at lokale tjenestesteder har blitt lagt ned. Så langt har miljøkriminalitet ikke blitt styrket sentralt i de nye distriktene. Politireformene har forverret situasjonen lokalt (Sørlie og Larsson 2018). Feltet er nedprioritert og tidligere

29. Det skjedde i Nord-Trøndelag hvor en tjenestemann ble dømt for grov uforstand i tjenesten i 2017. Han tipset mistenkte om hva han skulle svare under avhør i en etterforskning hvor han selv deltok. https://www.dagbladet.no/nyheter/politimann-skulle-laere-ulvejeger-a-slippestraff-i-nattlige-sms-er/68964850 
nettverk med politikontakter er flere steder borte. De som arbeider med miljø dekker et svært omfattende felt, oftest i en deltidsstiling. Dette i fylker med mange utfordringer i forhold til både flora og fauna. En oppsynsmann uttrykker det slik: «Politiet har ikke ressurser, kanskje ikke interesse, i alle fall ikke lokalt.»

Det er ikke mindre problematisk med kompetansen innen feltet lokalt. Noe av dette henger sammen med lite erfaring. Selv blant «ekspertene» på feltet var det vanlig at de hadde etterforsket ytterst få saker hvis en inkluderer hele spekteret av rovdyrrelaterte forhold. Det er ikke alltid like enkelt å skille manglende kompetanse med manglende vilje og interesse. De fleste av min informanter lokalt hadde erfaring fra en eller to saker av denne arten.

De seneste tiår har det skjedd en dreining i retning av at SNO har fått en mer sentral rolle i det polisiære arbeidet på feltet. ${ }^{30}$ SNO har styrket sin rolle samtidig med at det lokale politiet har forsvunnet ut av skogen. Det er interessant å merke seg at den første SNO direktøren hadde bakgrunn fra Kripos og var en bekjent av Riksadvokaten. Etter SNO ble etablert i 1996 var forholdet til politiet, særlig de stedene i landet hvor politiet hadde utviklet lokalkompetanse innen feltet tilspisset. ${ }^{31}$ Dette synes nå mer avklart. SNO utfører kontroll ute, men minst like viktig er deres bistandsoppgaver. I mange tilfeller er SNO først «på åstedet» og de sikrer funnene og kan ofte gjøre en første vurdering av forholdet. En del av det ordinære arbeidet til SNO har preg av etterforskning. De skal fastslå dødsårsak hvor det er mistanke om rovdyrtap og tilkalles også ved andre forhold. En oppsynsmann forteller: «Arbeidet med disse sakene (saker med drepte husdyr eller bufe), men også med skadeskyting eller andre forhold bærer preg av etterforskningsarbeid. Forholdene må dokumenteres, mye kunnskap går inn i å avdekke hva som har skjedd. SNO læres opp i etterforskning i slike saker.» SNO har de senere årene blitt opplært av politiet i korrekt sikring av åsted.

\section{Høy eller lav politivirksomhet?}

Proaktiv og reaktiv etterforskning krever ulik kompetanse. Proaktive metoder bygger på innsats mot identifiserte miljøer eller personer hvor det benyttes etter-

30. Innen særlig amerikanske studier har spørsmålet om oppsynsmenn - rangers, wardens - har fått mer tradisjonelle politioppgaver blitt reist av flere (Eliason 2016, Patten, Crow \& Shelley 2015). Dette spørsmål er mindre aktuelt i Norge, mange av de amerikanske tilsynene har full politimyndighet og kan ligne mer på lokale lensmenn med særskilt ansvar for natur og miljø.

31. Nord- Trøndelag nevnes som særlig vanskelig, hvor politidistriktet hadde utviklet nasjonal kompetanse på feltet. 
retnings- og overvåkningsmetoder for å samle informasjon. Mest brukt er kommunikasjonskontroll, politiet kan også ha informanter i miljøer eller forsøke å infiltrere dem (Larsson 2014, Økokrim 1994). Metodene er ikke nye, men har en forhistorie fra politisk overvåkning og senere opp mot organisert kriminalitet og terror (Larsson 2014 og 2018a). Det finnes i liten grad kompetanse eller ressurser til å sette i gang proaktiv etterforskning på miljøfeltet på distriktsnivå og ennå mindre lokalt. Om metodene skal brukes kommer spesialister fra Kripos og Økokrim oftest inn i bildet. I de nordiske land er bruken av slike metoder på miljøfeltet uvanlig og ny, sakene nevnt i denne artikkelen er blant de fă, men flere andre land, kanskje særlig USA, har tilnærmingen vært brukt i lengre tid (Økokrim 1994).

Metodebruken kan forstås i lys av hva Brodeur (2010) kaller high and low policing. Han betegner high policing på flere vis, men som den formen for politiarbeid som historisk sett er knyttet opp mot politisk overvåkning hvor informanter, bruk av infiltrasjon, skjult og sivilt politi var blant kjennetegnene. Motsetningen er politiarbeid rettet mot «ordinær kriminalitet» ute i det offentlige rom vanligvis gjerninger begått av personer med sammensatte sosiale problemer samt gamle kjenninger (Felson 1998).

Innen studier av økonomisk kriminalitet skilles det mellom kriminalitet som er mala prohibita og mala in se (Schlegel 1990, Larsson 2002). Mala prohibita er lovbrudd hvor det i utgangspunktet ikke finnes entydige normer i befolkningen, eller hvor de er omstridt, som skiller mellom rett eller galt. Innsidehandel og kursmanipulasjon er to eksempler. Slike saker anmeldes sjelden av publikum, ofte finnes ikke et konkret offer. De er derfor avhengig av regulering og kontrollvirksomhet for å avdekkes og anmeldes. Mala in se er lovbrudd hvor befolkningen jevnt over har en normativ forståelse av handlingene som gale. Det er ofte et offer som anmelder. Typisk kan være tyverier og en del former vold.

Etterforskning av mala prohibita deler noen grunnleggende kjennetegn, de bygger på at politi eller andre kontrolletater anmelder, verdien av hva vitner kan bidra med er mer usikkert, ofte kreves teknisk ekspertise for i det hele tatt å forstå sakene, de kan være komplekse, bevis må letes opp, de kan bygge på et bredt spekter av ulike bevis som må fortolkes og tidvis være juridisk krevende. Som en etterforsker som hadde erfaring fra flere ulvesaker sier det: «Teknisk er viktig, men det viktigste er sammenhengen mellom alle bevis i saken.» Illegal ulvejakt er et godt eksempel på et mala prohibita.

Ulven er omstridt. For noen er den et positivt symbol, ulvens tilbakekomst ses som en berikelse og vitalisering av naturen, andre ser den som noe som truer sau, elg og nærmest livsgrunnlaget i bygdene. Selv om lovverket er tydelig på vern, er 
beskatningen av arten slik at den holdes på et absolutt minimum (Sollund 2017). Sentrale myndigheter signaliserer en dobbelthet. At det finnes en viss normativ aksept for illegal jakt, særlig i visse områder bør ikke forundre (Krange og Skogen 2018, 2019, Larsson 2018). Likevel er det viktig å understreke at «folk flest», også i landlige distrikter, er positivt innstilt. Uenighetene blir tydeligst når det gjelder størrelsen på bestanden og forvaltningen. Det kan hevdes at den danske situasjonen er forskjellig fra eksempelvis den norske når Danmark er tett befolket og med lite «villmark». Det er riktig. Samtidig er konflikten overraskende lik (Krange, Skogen og Figari 2013). Det handler også i Norge mye om at lokalbefolkning i media uttrykker utrygghet og innskrenking av egen livssituasjon ved å få ulven tett på. Sannsynligheten for at folk bevitner og anmelder ulvedrap er derimot større i Danmark enn i Norge.

Brodeur (2010) påpeker at det ofte er slik at politiet bruker low policing methods against high policing crimes innen feltet økonomisk kriminalitet. I mange tilfeller er ikke illegal ulvejakt noen high crime, mange av sakene er enkle, preget av at muligheten byr seg. Vanligvis er de skjult og vil stort sett oppdages om jegeren er riktig uheldig, nærmest uansett hvilken tilstedeværelse SNO og politiet har ute i terrenget. Bruken av skjulte metoder, proaktiv etterforskning skal kun være for alvorlig kriminalitet fordi de truer flere grunnleggende samfunnsverdier. De er inngripende i folks privatliv, integritetskrenkende, det er metoder som utgir seg for å være noe annet enn de er, dette gjør også at det stilles strenge krav for å få tilgang til å bruke dem (NOU 2009:15 Larsson 2018). I ulvesakene de har vært benyttet har det knapt blitt stilt spørsmål ved metodebruken, men heller prioriteringer og ressursbruk. Den offentlige oppmerksomhet rundt bruken av metodene i Norge er nærmest fraværende. Det er god grunn til skepsis mot metodene. På den annen side, om politiet skal etterforske mer enn tilfeldige enkeltsaker er det knapt andre muligheter som byr seg.

\section{Litteratur}

Bacon, Matthew (2016). Taking Care of Business. Police Detectives, Drug Law Enforcement and Proactive Investigation, Clarendon Studies in Criminology, Oxford. https://doi.org/10. 1093/acprof:oso/9780199687381.001.0001

Benson, Michael L. og Francis T. Cullen (1998). Combating Corporate Crime. Local Prosecutors at work, Northwestern University Press.

Bjärvall, Anders og Robert Franzén (2017). Storskalig illegal jakt i Norrbotten, i Våra Rovdjur nr. 3, 2017. https://www.rovdjur.se/objfiles/1/JaktharvaniNorr_-887329052.pdf

Brodeur, Jean-Paul (2010). The Policing web, Oxford University Press, Oxford. https://doi.org/ 10.1093/acprof:oso/9780199740598.001.0001 
BRÅ (2007). Illegal jakt på stora rovdjur. Konflikt i laglöst land?, BRÅ rapport 2007:22, Stockholm.

Dagbladet (des 2017) Politimann skulle lære ulvejeger å slippe straff i nattlige sms-er. https://www.dagbladet.no/nyheter/politimann-skulle-laere-ulvejeger-a-slippe-straff-inattlige-sms-er/68964850

Dagbladet (sept 2018). Politimann dømt etter SMS til ulvejeger. https://www.dagbladet.no/ nyheter/politimann-domt-etter-sms-til-ulvejeger/70246500

Dagsavisen (mars 2019) Giftblandere i skuddlinja. https:/www.dagsavisen.no/nyheter/ innenriks/giftblandere-i-skuddlinja-1.1450070

Dahl, Johanne Yttri (2019). Spaningsblikket - en utforskning av politispaneres lesning av omgivelsene, Tidsskrift for samfunnsforskning nr. 3. https://doi.org/10.18261/issn.1504-291X2019-03-01

DR (2018) Fire ulver er væk: vi skal se tett på nul ulve som muligt sier V-ordfører. https:/www.dr.dk/nyheder/regionale/midtvest/fire-ulve-er-vaek-vi-skal-saa-taet-paa-nul-ulvesom-muligt-mener-v

DR (2018) Ulvedrab ved Ulfborg blev fanget på kamera, her er videoen. https://www.dr.dk/ nyheder/indland/ulvedrab-ved-ulfborg-blev-fanget-paa-kamera-her-er-videoen

DR (2019) Ulvedom: 67 årig får 40 dages betinget fængsel og mister jagttegn. https://www.dr.dk/ nyheder/regionale/midtvest/ulvedom-67-aarig-faar-40-dages-betinget-faengsel-og-misterjagttegn

Eliason, Stephen L. (2016). Game warden perceptions of change in conservation law enforcement, i The Police Journal: Theory, Practice and Principles 1-9.

Essen, Erica von (2016). In the gap between legality and legitimacy, illegal hunting in Sweden as a crime of dissent. SLU Doctoral thesis, Uppsala.

Felson, Marcus (1998). Crime \& Everyday Life, Sec. ed. Pine Forge Press.

Glåmdalen (2019). «Bonde sier han skjøt ulv for å verge sauene - politiet vil finne ut om ulven var i angrep.» https://www.glomdalen.no/ulv/ulvejakt/rovdyr/bonde-sier-han-skjot-ulv-for-averge-sauene-politiet-vil-finne-ut-om-ulven-var-i-angrep/s/5-19-634705

Glåmdalen (2019). «Emilie Enger Mehl ut mot mediene etter ulveskytingen i Sør-Odal: - Ut fra medias framstilling kunne det like gjerne vært drap på et menneske.» https://www.glom dalen.no/ulv/rovdyr/media/emilie-enger-mehl-ut-mot-mediene-etter-ulveskytingen-i-sor-odalut-fra-medias-framstilling-kunne-det-like-gjerne-vart-drap-pa-et-menneske/s/5-19-634834

Høviskeland, Tore (2016). Leder, i Miljøkrim. https://www.okokrim.no/leder.416615.no.html

Johansen, Per Ole (1977). Menstadkonflikten 1931, Tiden forlag.

Krange, Olve (2018). Hva skal vi med ulven? på Rovdyrbloggen, Forskning.no https://blogg. forskning.no/rovdyrbloggen/hva-skal-vi-med-ulv-egentlig/1229597

Krange, Olve og Ketil Skogen (2018). Nordmenns holdninger til ulv, NINA rapport 1570. https://brage.nina.no/nina-xmlui/handle/11250/2577847

Krange, Olve og Ketil Skogen (2019). Ulovlig jakt på store rovdyr. Holdninger i befolkningen, lokalsamfunn og blant jegere. NINA rapport, 1663. https://brage.nina.no/nina-xmlui/handle/ $11250 / 2599697$

Krange, Olve, Ketil Skogen og Helene Figari (2013). Ulvekonflikter - en sosiologisk studie, Akademika.

Larsson, Paul (2002). I lovens grenseland, Pax forlag. Oslo. 
Larsson, Paul (2014). Å danse med djevelen. Rapport fra Nsfk seminar.

Larsson, Paul (2018). Organisert kriminalitet, 2 utgave, Pax Oslo.

Larsson, Paul (2018b). «On the hunt: aspects on the use of communication control in Norway», $i$ Fyfe, Gundhus og Rønn (eds.). Moral issues in intelligence-led policing, Routledge.

Lenth, Lars, Petter Bøckman og Morten Tønnessen (2017). Ulvetider. Rovdyret som splittet Norge, Vega Forlag, Oslo.

Liberg, Olof et.al (2011). Shoot, shovel and shut up: cryptic poaching slows restoration of a large carnivore in Europe, Proceedings of the Royal Society B, online: https://www.ncbi.nlm. nih.gov/pmc/articles/PMC3259920/. https://doi.org/10.1098/rspb.2011.1275. PMid:21849323 PMCid:PMC3259920

Mawby, Rob I. og Richard Yarwood (2011). Rural policing and policing the rural. A Constable Countryside, Routledge.

Meld. St. 21 (2015-2016). Ulv i norsk natur - Bestandsmål for ulv og ulvesone. https:/www.regjeringen.no/no/dokumenter/meld.-st.-21-20152016/id2480008/

Nationen (2017). Den døde ulven i Rena var fra Julussareviret. https://www.nationen.no/distrikt/ den-dode-ulven-i-rena-var-fra-julussa-reviret/

Netnatur.dk. Rettens begrundelse for ulvedommen. https://www.netnatur.dk/rettens-begrundel se-for-ulvedommen/

Newburn, Tim (2011). »Understanding investigation«, i Newburn, Williamson and Wright (eds.). Handbook of Criminal Investigation, Routledge, London. https://doi.org/10.4324/ 9780203118177

Norrbottens kuriren (2016). Nya uppgifter: fäm män gripna vid stor polisinsats. https://www.ku riren.nu/nyheter/nya-uppgifterfem-man-gripna-vid-stor-polisinsats-8966944.aspx

NOU2009:15 Skjult informasjon - åpen kontroll - Metodekontrollutvalgets evaluering av lovgivningen om politiets bruk av skjulte tvangsmidler og behandling av informasjon i straffesaker, Offentlig utredning.

NRK (2011). Skjøt ulv og ringte politiet. https://www.nrk.no/ostlandssendingen/ulv-skutt-i-nes1.7753865

NRK (2016). Hevder ulven ble skutt i nødverge. https://www.nrk.no/trondelag/hevder-ulvenble-skutt-i-nodverge-1.13197901

NRK (des. 2016) Ulveskytter: - Opplevde situasjonen som truende og skremmende https://www.nrk.no/ho/ulveskytter_-_-opplevde-situasjonen-som-truende-og-skremmende1.13261543

NRK (mars 2002) Fengsel for ulveforgifter. https://www.nrk.no/norge/fengsel-for-ulveforgifter1.504679

NRK (juni 2002) Dømt for å ha lagt ut giftåte. https://www.nrk.no/norge/domt-for-a-lagt-utgiftate-1.505846

NTB (16.09.2019) Elgjeger dømt for å ha skutt ulv. https://www.msn.com/nb-no/nyheter/ norge/elgjeger-dømt-til-fengsel-for-å-ha-skutt-ulv/ar-AAHnDpm?ocid=spartanntp

Patten, Ryan; Matthew S. Crow \& Tara O'Connor Shelley (2015). What's in a Name? The Occupational Identity of Conservation and Natural Resource Oriented Law Enforcement Agencies, American Journal of Criminal Justice 40:750-764. https://doi.org/10.1007/s12103-0149286-y 
Schlegel, Kip (1990). Just Desert for Corporate Criminals, North Eastern University Press, Boston.

Slettemoen, Aud Ingvild (2013). Fengselsstraff for ulvedrap, i Miljøkrim, Nr. 1 - årgang 16.

Sollund, Ragnhild (2017). The animal other: legal and illegal theriocide, https://www.research gate.net/publication/322103188_The_animal_other_Legal_and_illegal_theriocide

Sollund, Ragnhild (2017b). Perceptions and law enforcement of illegal and legal wolf killing in Norway: organized crime or folk crime? Palgrave Communications 3. https://doi.org/10. 1057/palcomms.2017.59. https://www.nature.com/articles/palcomms201759

Sørlie, Vanja L og Paul Larsson (2018). Politireformer, Cappelen-Damm forlag, Oslo.

Ulve (Canis Lupus) i Danmark 2012-2017, Aarhus Universitet og Naturhistorisk Museum Aarhus (rapport). https://dce2.au.dk/pub/SR258.pdf

VG (2009). Vil styrke innsatsen mot illegal ulvejakt, https://www.vg.no/nyheter/innenriks/i/ 6xplr/vil-styrke-innsatsen-mot-ulovlig-ulvejakt

Økokrim (1994). Faunakriminalitet og annen naturkriminalitet, ØKOKRIMs skriftserie nr. 8, Oslo. 